\title{
PENDAMPINGAN PERANAN DAN FUNGSI KEMASAN PRODUK DALAM DUNIA PEMASARAN DESA YOSOWILANGUN LOR
}

\author{
Emmy Ermawati \\ STIE Widya Gama Lumajang \\ emmy.ermawati01@gmail.com
}

\begin{abstract}
Abstrak
Kemasan yang dirancang dengan desain yang bagus dan terkonsep dengan matang akan menimbulkan persepsi dalam benak konsumen bahwa produk yang ditawarkan berkualitas bagus. Oleh karena itu, pemilik brand memiliki tim khusus yang melibatkan desainer produk maupun desainer grafis profesional untuk merancang kemasan produk yang tak hanya memiliki nilai fungsional tapi juga nilai estetika yang tinggi. Merancang desain kemasan yang efektif memerlukan pengetahuan yang luas mulai dari desain produk hingga strategi pemasaran. Oleh karena itu disinilah fungsi dari pengabdian masyarakat ini diberikan agar masayarakat memahami terkait model kemasan, design logo kemasan, stiker kemasan, membuat olahan tahan lama.
\end{abstract}

Kata kunci : Model Kemasan, design logo kemasan, stiker kemasan, membuat olahan menjadi tahan lama.

\begin{abstract}
Packaging that is designed with a good design and conceptualized will cause a perception in the minds of consumers that the products offered are of good quality. Therefore, brand owners have a special team that involves product designers and professional graphic designers to design product packaging that not only has functional value but also high aesthetic value. Designing effective packaging designs requires extensive knowledge from product design to marketing strategies. Therefore this is where the function of community service is given so that the community understands the related packaging model, packaging logo design, packaging stickers, making durable preparations.
\end{abstract}

Key words: Packaging model, packaging logo design, packaging stickers, make preparations become durable

\section{PENDAHULUAN}

Pada dasarnya, kemasan didesain untuk menyimpan produk, melindungi produk dari kerusakan yang diwujudkan dalam berbagai macam bentuk dan ukuran. Namun, dalam dunia pemasaran, kemasan lebih dari sekadar alat pembungkus atau penyimpan produk semata. Kemasan produk (packaging) berfungsi pula sebagai media pemasaran dan branding yang sengaja dirancang untuk membangun brand image dalam benak konsumen.

Kemasan yang dirancang dengan desain yang bagus dan terkonsep dengan matang akan menimbulkan persepsi dalam benak konsumen bahwa produk yang ditawarkan berkualitas bagus. Oleh karena itu, pemilik brand memiliki tim khusus yang melibatkan desainer produk maupun desainer grafis profesional untuk merancang kemasan produk yang tak hanya 
memiliki nilai fungsional tapi juga nilai estetika yang tinggi. Merancang desain kemasan yang efektif memerlukan pengetahuan yang luas mulai dari desain produk hingga strategi pemasaran.

Bagi konsumen, kemasan dapat membantu mereka mengenali lebih dalam tentang produk yang ditawarkan. Caranya yaitu dengan membaca informasi yang ditampilkan pada kemasan produk. Informasi yang dimuat pada packaging hendaknya merupakan hal-hal yang penting diketahui oleh konsumen. Misalnya, komposisi produk, tanggal kadaluwarsa, cara pemakaian hingga nomor customer service yang memudahkan konsumen untuk mendapatkan informasi lebih jauh.

Banyak pengusaha home industri di daerah yosowilangun Lor yang mengembangkan berbagai olah seperti kripik, jamu, krupuk dan minuman instan yang nota bane pada masalah kemasan mereka sangat kurang sekali pengetahuannya. Oleh karena itu perlu adanya pendampingan dalam pengolahan kemasan yang baik agar produk lebih memiliki nilai jual yang tinggi.

Permasalahan mitra yang dihadapi pada pembuatan kemasan produk adalah : model kemasan, design logo kemasan, stiker kemasan, membuat olahan menjadi tahan lama. Dari permasalahan tersebut coba saya jelaskan satu persatu beserta contohnya supaya masing masing dari UKM memahami dan berupaya untuk memperbaiki produk yang mereka hasilkan dengan bernilai tambah yang signifikan.

\section{METODE PELAKSANAAN}

Ada beberapa metode pendekatan yang digunakan dalam pelaksanaan program, meliputi:

a. Pelatihan Program pengabdian kepada masyarakat dilaksanakan dalam bentuk pelatihan kepada mitra pelaku usaha UKM di Desa Yosowilangun Lor Kecamatan Yosowilangun. Pelatihan tersebut berupa pemaparan materi kepada mitra terkait permasalahan yang dihadapi mitra yaitu aspek pengemasan yang menarik dan tahan lama. Materi yang akan disampaikan diharapkan dapat memberikan peningkatan pengetahuan dan pemahaman untuk selanjutnya dapat diterapkan oleh mitra dalam kegiatan usaha.

b. Diskusi setelah materi selesai dipaparkan, dilanjutkan dengan diskusi berupa tanya jawab antara pemateri dengan peserta. Diskusi dilakukan agar peserta lebih memahami materi yang telah disampaikan. Melalui diskusi, pelatihan tidak hanya sekedar transfer knowledge saja melainkan dapat sharing pengalaman maupun permasalahan yang sedang dihadapi mitra.

\section{HASIL DAN PEMBAHASAN}

Pelatihan ini dilaksanakan di Balai Desa Yosowilangun Lor Kabupaten Lumajang dengan diikuti oleh 20 peserta yang mempunyai usaha home industri di bidang batik, kripik, jamu dan berbagai oalahan ikan serta bunga hias. Kami membahas tentang funsi pengemasan itu sendiri yang mana pengemasan adalah suatu proses pembungkusan, pewadahan atau pengepakan suatu produk dengan menggunakan bahan tertentu sehingga produk yang ada di dalamnya bisa tertampung dan terlindungi. Sedangkan kemasan produk adalah bagian pembungkus dari suatu produk yang ada di dalamnya. Pengemasan ini merupakan salah satu cara untuk mengawetkan atau memperpanjang umur dari produk-produk pangan atau makanan yang terdapat didalamnya.

Teknologi Pengemasan terus berkembang dari waktu ke waktu dari mulai proses pengemasan yang sederhana atau tradisional dengan menggunakan bahan-bahan alami seperti dedaunan atau anyaman bambu sampai teknologi modern seperti saat ini. Dalam teknologi pengemasan modern misalnya jaman dulu orang membuat tempe di bungkus dengan daun pisang atau daun jati, membungkus gula aren dengan daun kelapa atau daun pisang kering. Teknologi pengemasan yang semakin maju dan modern telah hampir meniadakan penggunaan 
bahan pengemas tradisional. diantara contoh-contoh pengemasan modern diantaranya menggunakan bahan plastik, kaleng/logam, kertas komposit, dan lain sebagainya.

Pengemasan merupakan salah satu faktor yang sangat penting dan mutlak diperlukan dalam persaingan dunia usaha seperti saat ini. Saat ini kemasan merupakan faktor yang sangat penting karena fungsin dan kegunaanya dalam meningkatkan mutu produk dan daya jual dari produk.

Kemasan produk dan labelnya selain berfungsi sebagai pengaman produk yang terdapat di dalamnya juga berfungsi sebagai media promosi dan informasi dari produk yang bersangkutan. Kemasan produk yang baik dan menarik akan memberikan nilai tersendiri sebagai daya tarik bagi konsumen. Namun demikian, sampai saat ini kemasan produk masih merupakan masalah bagi para pengelola usaha, khususnya Usaha Mikro Kecil dan Menengah. Permasalahan tentang kemasan produk dan labelnya kadang-kadang menjadi kendala bagi perkembangan atau kemajuan suatu usaha. Banyak persoalan yang muncul ketika suatu usaha ingin memiliki suatau kemasan produk yang baik, berkualitas dan memenuhi standar nasional yang ada. Persoalan-persoalan yang sering dihadapi seperti bahan pengemas, desain bentuk kemasan, desain label, sampai pada persoalan yang paling utama yaitu biaya pembuatan kemasan itu sendiri.

Bagi para pengelola UMKM dengan segala keterbatasan modal usaha sebaiknya permasalahan tentang kemasan bisa ditangani dengan kreativitasnya. Kemasan yang baik dan menarik tidak selalu identik dengan harga kemasan yang mahal. Dengan bahan pengemas yang biasa-biasa saja, asalkan dirancang sedemikian rupa baik bentuk maupun desain labelnya pastilah akan tercipta sebuah kemasan yang tidak kalah bersaing dengan kemasankemasan modern.

\section{A.Fungsi dan Kegunaan Kemasan}

Kami sampaikan bahwa fungsi kemasan merupakan faktor penting dalam sebuah usaha pengolahan makanan karena fungsi dan kegunaan dari kemasan itu sendiri. Secara umum fungsi kemasan adalah sebagai bahan pelindung atau pengaman produk dari pengaruhpengaruh luar yang dapat mempercepat terjadinya kerusakan pada makanan yang terdapat di dalamnya. Namun demikian selain itu kemasan masih memiliki fungsi-fungsi atau kegunaan lain yang tidak kalah pentingnya seperti mempermudah distribusi atau pengontrolan produk dan bahkan saat ini ada fungsi yang sangat penting yaitu kemasan sebagai media atau sarana informasi dan promosi dari produk yang ditawarkan yang ada di dalam kemasan.

Secara lebih terperinci berikut ini adalah sekilas penjelasan singkat tentang fungsi dan peranan kemasan dalam usaha pengolahan makanan :

1. Sebagai wadah, perantara produk selama pendistribusian dari produsen ke konsumen.

2. Sebagai Pelindung, kemasan di harapkan dapat melindungi produk yang ada di dalamnya dari berbagai faktor penyebab kerusakan baik yang disebabkan oleh faktor biologi, kimia maupun fisika.

3. Memudahkan pengiriman dan pendistribusian, dengan pengemasan yang baik suatu produk akan lebih mudah didistribusikan.

4. Memudahkan penyimpanan, Suatu produk yang telah dikemas dengan baik akan lebih mudah untuk di simpan.

5. Memudahkan penghitungan, dengan pengemasan jumlah atau kuantitas produk lebih mudah di hitung.

6. Sarana informasi dan promosi. Informasi-informasi mengenai produk yang terdapat di dalamnya seperti komposisi produk, kandungan gizi, khasiat atau manfaat produk

B. Penggolongan Kemasan

Menurut Julianti dan Nurminah (2006), Kemasan dapat diklasifikasikan berdasarkan beberapa hal atau beberapa cara yaitu sebagai berikut : 
1. Klasifikasi kemasan berdasarkan frekwensi pemakaian :

- Kemasan sekali pakai (disposable), yaitu kemasan yang langsung dibuang setelah dipakai, seperti kemasan produk instant, permen, dll.

- Kemasan yang dapat dipakai berulangkali (multitrip) dan biasanya dikembalikan ke produsen, contoh : botol minuman, botol kecap, botol sirup.

- Kemasan atau wadah yang tidak dibuang atau dikembalikan oleh konsumen (semi disposable), tapi digunakan untuk kepentingan lain oleh konsumen, misalnya botol untuk tempatair minum dirumah, kaleng susu untuk tempat gula, kaleng biskuit untuk tempat kerupuk, wadah jam untuk merica dan lain-lain.

2. Klasifikasi kemasan berdasarkan struktur sistem kemas (kontak produk dengan kemasan) :

- Kemasan primer, yaitu kemasan yang langsung bersentuhan dengan produk yang di bungkusnya.

- Kemasan sekunder, yang tidak bersentuhan langsung dengan produknya akan tetapi membungkus produk yang telah dikemas dengan kemasan primer

- Kemasan tersier dan kuartener yaitu kemasan untuk mengemas setelah kemasan primer atau sekunder.

3. Klasifikasi kemasan berdasarkan sifat kekauan bahan kemasan :

- Kemasan fleksibel yaitu bahan kemasan yang mudah dilenturkan tanpa adanya retak atau patah. Misalnya plastik, kertas dan foil.

- Kemasan kaku yaitu bahan kemas yang bersifat keras, kaku, tidak tahan lenturan, patah bila dibengkokkan relatif lebih tebal dari kemasan fleksibel. Misalnya kayu, gelas dan logam.

- Kemasan semi kaku/semi fleksibel yaitu bahan kemas yan memiliki sifat-sifat antara kemasan fleksibel dan kemasan kaku. Misalnya botol plastik (susu, kecap, saus), dan wadah bahan yang berbentuk pasta.

4. Klasifikasi kemasan berdasarkan sifat perlindungan terhadap lingkungan :

- Kemasan hermetis (tahan uap dan gas) yaitu kemasan yang secara sempurna tidak dapat dilalui oleh gas, udara atau uap air sehingga selama masih hermetis wadah ini tidak dapat dilalui oleh bakteri, kapang, ragi dan debu. Misalnya kaleng, botol gelas yang ditutup secara hermetis.

- Kemasan tahan cahaya yaitu wadah yang tidak bersifat transparan, misalnya kemasan logam, kertas dan foil. Kemasan ini cocok untuk bahan pangan yang mengandung lemak dan vitamin yang tinggi, serta makanan hasil fermentasi.

- Kemasan tahan suhu tinggi, yaitu kemasan untuk bahan yang memerlukan proses pemanasan, pasteurisasi dan sterilisasi. Umumnya terbuat dari logam dan gelas.

5. Klasifikasi kemasan berdasarkan tingkat kesiapan pakai (perakitan) :

- Wadah siap pakai yaitu bahan kemasan yang siap untuk diisi dengan bentuk yang telah sempurna. Contoh : botol, wadah kaleng dan sebagainya.

- Wadah siap dirakit / wadah lipatan yaitu kemasan yang masih memerlukan tahap perakitan sebelum diisi. Misalnya kaleng dalam bentuk lembaran (flat) dan silinder fleksibel, wadah yang terbuat dari kertas, foil atau plastik.

\section{Jenis-jenis bahan Kemasan}

Bahan atau material kemasan ada bermacam macam jenis dan masing-masing jenis bahan pengemas memiliki sifat, keuntungan dan kelemahan yang berbeda-beda. Tidak bisa dipungkiri bahwa dengan berkembangnya Ilmu Pengetahuan dan teknologi semakin 
berkembang pula ilmu pengetahuan dalam bidang pengemasan khususnya material atau bahan kemasan. Bahan-bahan pengemas yang ada saat ini dimulai dari yang sederhana sampai bahan-bahan canggih yang dihasilkan dengan teknologi yang canggih pula. Semakin baik kualitas atau semakin canggih bahan kemasan tentu akan berbanding lurus dengan harga atau biaya yang dibutuhkan untuk mendapatkan atau menggunakannya. Bahan-bahan kemasan yang ada saat ini diantaranya adalah kertas, plastik, gelas, kaleng/logam dan kemasan komposit yang merupakan perpaduan dari dua atau lebih bahan pengemas.

\section{Desain Kemasan}

Kemasan agar menarik harus dirancang dan dibuat sebaik mungkin, dalam merancang atau merencanakan pembuatan suatu kemasan sebaiknya kita memperhatikan hal-hal seperti berikut ini :

1. Kesesuaian antara produk dengan bahan pengemasnya

Maksudnya adalah dalam menentukan bahan pengemas kita harus mempertimbangkan produk yang kita miliki. Jika produk kita berbentuk cairan seperti jus atau sirup, kita bisa memilih bahan pengemas seperti botol atau gelas plastik. Jika produk kita berupa makanan kering seperti keripik, kerupuk, atau yang lainnya kita bisa menggunakan plastik transparan dan lain sebagainya. Plastik dapat digunakan sebagai kemasan primer sekaligus dengan labelnya, juga bisa dimasukkan kedalam kemasan lain seperti dus kertas sebagai kemasan sekunder.

2. Ukuran Kemasan dan ketebalan bahan kemasan

Ukuran kemasan berkaitan dengan banyak sedikitnya isi yang diinginkan, sedangkan ketebalan berkaitan dengan keawetan dari produk yang ada didalamnya. Jika produknya sangat ringan seperti kerupuk sebaiknya kemasan di buat dalam ukuran relatif besar

3. Bentuk kemasan. Agar kemasan menarik bentuk pengemas bisa dirancang dalam bentuk yang unik tergantung dari kreativitas perancangnya. Misalnya kemasan dus kertas bisa di buat seperti tabung, kubus, balok, trapesium atau bentuk-bentuk lainnya.

\section{E. Desain label}

Label adalah suatu tanda baik berupa tulisan, gambar atau bentuk pernyataan lain yang disertakan pada wadah atau pembungkus sebagai yang memuat informasi tentang produk yang ada di dalamnya sebagai keterangan/ penjelasan dari produk yang dikemas. Label kemasan bisa dirancang atau didesain baik secara manual menggunakan alat lukis atau yang lainnya maupun menggunakan software komputer. Desain yang dibuat secara manual mungkin akan mengalami sedikit kesulitan ketika mau digunakan atau diaplikasikan sedangkan dengan menggunakan komputer tentunya akan lebih mudah.

Dewasa ini keberadaan software - software komputer sangat membantu para desainer untuk merancang desain label yang baik, menarik, dan artistik sehingga dapat meningkatkan daya tarik produk terhadap konsumen. Suatu produk yang sama jika dikemas dalam kemasan dengan desain label berbeda sangat dimungkinkan daya jualnya juga berbeda. Merancang atau mendesain label kemasan sangatlah tergantung pada kreativitas para desainernya, baik ukuran, bentuk, maupun corak warnanya. Namun demikian ada hal-hal yang harus diperhatikan dalam membuat label kemasan yaitu :

1. Label tidak boleh menyesatkan

Apa saja yang tercantum dalam sebuah label baik berupa kata-kata, kalimat, nama, lambang, logo, gambar dan lain sebagainya harus sesuai dengan produk yang ada di dalamnya.

2. Memuat informasi yang diperlukan

Label sebaiknya cukup besar (relatif terhadap kemasannya), sehingga dapat memuat informasi atau keterangan tentang produknya.

3. Hal-hal yang seharusnya ada atau tercantum dalam label produk makanan adalah sebagai berikut : 
- Nama produk

Nama Produk adalah nama dari makanan atau produk pangan yang terdapat di dalam kemasan misalnya dodol nanas, keripik pisang, keripik singkong dan lain sebagainya.

- Cap / Trade mark bila ada

Suatu usaha sebaiknya memiliki cap atau trade mark atau merek dagang. Cap berbeda dengan nama produk dan bisa tidak berhubungan dengan produk yang ada di dalamnya misalnya dodol nanas cap "Panda", Kecap Ikan cap "Wallet", dsb.

- Komposisi / daftar bahan yang digunakan

Komposisi atau daftar bahan merupakan keterangan yang menggambarkan tentang semua bahan yang digunakan dalam pembuatan produk makanan tersebut. Cara penulisan komposisi bahan penyusun dimulai dari bahan mayor atau bahan utama atau bahan yang paling banyak digunakan sampai yang terkecil.

- Netto atau volume bersih

Netto atau berat bersih dan volume bersih menggambarkan bobot atau volume produk yang sesungguhnya. Apabila bobot produk berarti bobot produk yang sesungguhnya tanpa bobot bahan pengemas.

- Nama pihak produksi,

Nama pihak produksi adalah nama perusahaan yang membuat atau mengolah produk makanan tersebut.

- Distributor atau pihak yang mengedarkan bila ada.

Dalam kemasan juga harus mencantumkan pihak-pihak tertentu seperti pengepak atau importir bila ada.

- No Registrasi Dinas Kesehatan

Nomor registrasi ini sebagai bukti bahwa produk tersebut telah teruji dan dinyatakan aman untuk dikonsumsi.

- Kode Produksi

Kode produksi adalah kode yang menyatakan tentang batch produksi dari produk pada saat pembuatan yang isinya tanggal produksi dan angka atau hurup lainnya yang mencirikan dengan jelas produk tersebut.

- Keterangan kadaluarsa

Keterangan kadaluarsa adalah keterangan yang menyatakan umur produk yang masih layak untuk dikonsumsi. Menurut Julianti dan Nurminah (2006), keterangan kadaluarsa dapat ditulis Best before date : produk masih dalam kondisi baik dan masih dapat dikonsumsi beberapa saat setelah tanggal yang tercantum terlewati

Use by date : produk tidak dapat dikonsumsi, karena berbahaya bagi kesehatan manusia (produk yang sangat mudah rusak oleh mikroba) setelah tanggal yang tercantum terlewati. 


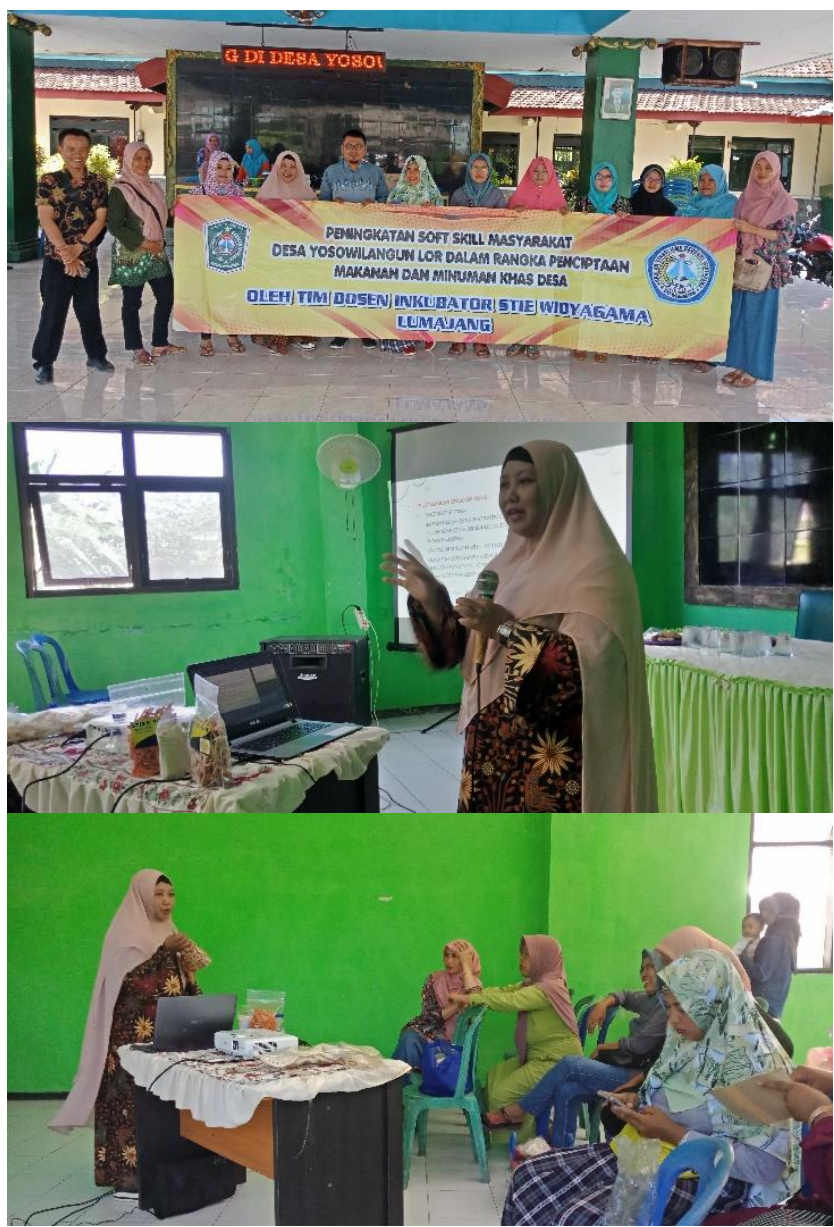

KESIMPULAN

Kemasan yang dirancang dengan desain yang bagus dan terkonsep dengan matang akan menimbulkan persepsi dalam benak konsumen bahwa produk yang ditawarkan berkualitas bagus. Oleh karena itu, pemilik brand memiliki tim khusus yang melibatkan desainer produk maupun desainer grafis profesional untuk merancang kemasan produk yang tak hanya memiliki nilai fungsional tapi juga nilai estetika yang tinggi. Merancang desain kemasan yang efektif memerlukan pengetahuan yang luas mulai dari desain produk hingga strategi pemasaran.

Dari penjelasan di atas maka peneliti dapat menyimpulkan sebagai berikut :

1. Pembungkus akan dapat memperlancar penjualan barang-barang bila perusahaan tidak menganggap fungsi pembungkus hanya sebagai pembungkus saja.

2. Dalam membuat pembungkus faktor-faktor keindahan praktis, ukuran, kemampuan melindungi dan sebagainya harus pula diperhatikan.

3. Pembungkus yang lebih mahal mungkin akan dapat menurunkan harga pokok, bilamana dengan pembungkus tersebut perusahaan akan mampu meningkatkan omset penjualan.

4. Perbedaan pembungkus dapat dilakukan untuk membedakan barang yang sama tetapi mempunyai ciri-ciri yang berbeda.

5. Kebijaksanaan merubah pembungkus harus tetap diusahan tidak jauh berbeda dengan pembungkus yang lama. 


\section{DAFTAR PUSTAKA}

Julianti, E. dan M. Nurminah. 2006. Buku Ajar Teknologi Pengemasan. Medan: Universitas Sumatera Utara - Press

Nitisemito, Alex Soemadji. 1981. Marketing. Jakarta; Ghalia Indonesia.

http://www.oocities.org/tethypermanasari/jangan_salah_pakai_dan_pilih_pla.htm http://ammarawirausaha.blogspot.com/2011/03/kemasan-yang-digunakan-untukmembungkus.html

http://bisnisukm.com/pentingnya-kemasan-produk.html

http://smsrbandung.wordpress.com/tag/pengertian-kemasan 